$$
\text { nคिمि }
$$



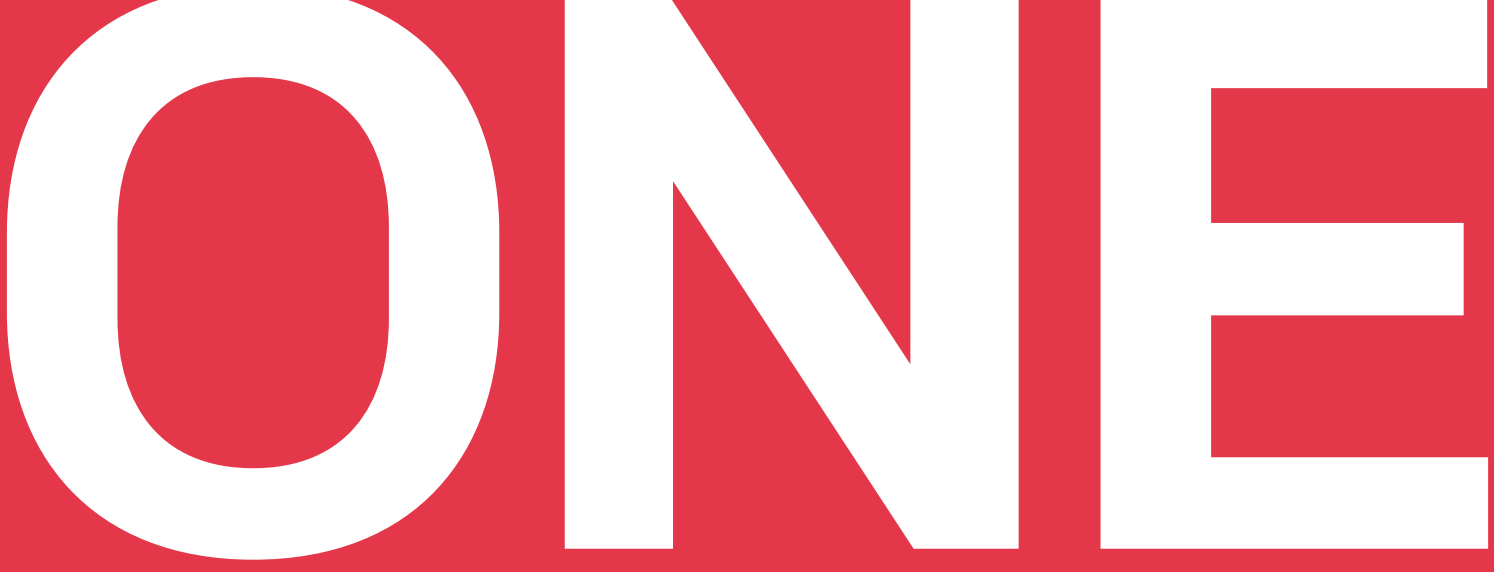

\section{CHAPTER 1 CONSUMER CULTURE STUDIES, A GLANCE AT THE LITERATURE'S CONTRIBUTIONS TO THE CONCEPT}

\section{AUTHORS:}

Eduardo Norman-Acevedo, Ma. Politécnico Grancolombiano Institución Universitaria

Juan Carlos Sosa Varela, PhD. University of Turabo of Puerto Rico

Adriana Bonomo, PhD. (c) Catholic University of Uruguay

Violeta Corona Cabrera, Ma. Pan-American University of Mexico 


\section{INTRODUCTION}

Publishing a book on consumer culture studies originates from the need to review research conducted on this subject. Among the expectations of Politécnico Grancolombiano Institución Universitaria, and as a result of reviews on the subject, this opportunity was identified within scientific literature. This book intends to be useful for readers by identifying international research trends in this field. It also aims to support the decision-making of marketing managers, with respect to consumers, and to have important input that fosters future research.

To do so, the institution introduces the structure of this editorial project, which first identified relevant authors and made an initial call to authors based on an approach to the state of the art by implementing a systematic literature review (SLR) (Kitchenham, 2004). The call made in August 2017 proposed that a select group of authors participate in the project with a chapter of its structure, given that they have indicated their interest in the subject. This proposal received great reception among those invited, including eight articles submitted, from which, after a rigorous selection process, contributions of five chapters were included at the date of publication with participation from international researchers who believed in our project.

Moreover, the project proposed establishing an editorial committee that provides academic support for the proposal. To do so, we sent out a call for academics with a PhD. Juan Carlos Sosa Varela, Chair and Associate Professor, University of Turabo of Puerto Rico, is completing Post-Doctoral Studies (PAG) at the Central American Institute of Business Administration in Alajuela, Costa Rica, PhD in International Business (School of Business Administration), University of Puerto Rico: San Juan and has research interests in international marketing, corporate responsibility, and branding. Lic ${ }^{1}$. Adriana Bonomo, Professor of high dedication at the Catholic University of Uruguay, holds a Doctorate in Business Administration (c) from "Santa Maria De Los Buenos Aires" Catholic University of Argentina, School of Social and Economic Sciences, with interests in Entrepreneurship and Marketing. Violeta Corona Cabrera holds a Master's Degree in Strategic Marketing from Pan-American University and is currently a professor in the Marketing Department at the Pan-American University of Mexico and has interests in market research, strategic planning, and marketing strategy. The institutional contribution is made by Eduardo Norman-Acevedo, Editorial Head and professor at Politécnico Grancolombiano Institución Universitaria. Master's Degree in Strategic Marketing Management and Expert in Communication and Dissemination of Science and Technology at the University of Oviedo, Asturias in Spain.

\footnotetext{
1. T.N.: Academic title used by professionals having a bachelor college degree in different fields.
} 
Within the development of the Master's Program in Marketing at the Politécnico Grancolombiano Institución Universitaria, frequently, expectations are identified in the academic community regarding the appearance of information from various sources, the interest in ensuring quality and its origin. Thus, institutional affiliation to reliable databases like Scopus allows the academic community to consult quality information. For this reason, from the institution, supported by the teaching staff, we started to create review publications, identifying key aspects during the training process of future teachers and hoping to encourage the use of this type of tool that contributes to the quality of production and teaching.

This chapter comprises the different stages used in the SLR, based on the SLR protocol proposed by (Kitchenham, 2004). It evaluates the existing literature in a database such as Scopus, in light of the publication, with a methodology that allows for replication or future review. "The interest in developing a systematic review arises from researchers' need to summarize existing information on knowledge in the marketing field, in a rigorous and impartial manner" (López, Méndez, Paz, \& Arboleda, 2016 p. 11). The goal is to establish a state of the art useful in the academic process of the institution.

The protocol includes systematically recording of the procedure, which enables us to contrast the information at different times to achieve conclusive results (Brereton, Kitchenham, Budgen, Turner, \& Khalil, 2007). The protocol used for this study is constructed from the 13 activities proposed by the aforementioned authors. These activities are divided into three clearly distinguished stages (in the order mentioned): planning, execution, and analysis (López et al., 2016).

"In the planning stage, the specific intention, as well as the approach, must be identified. This process includes writing out the objectives. The strategy considers all perspectives and outlines the development of relevant search strings to obtain the articles necessary for the SLR (Petersen, Feldt, Mujtaba, \& Mattsson, 2008 p. 146). The search query lays out the criteria for selecting the literature and applies inclusion and exclusion criteria using Boolean operators (Cream \& Verbano, 2013).

This chapter documents the process outlined to establish the publication's state of the art regarding consumers, from the Master's Program in Strategic Marketing Management at Politécnico Grancolombiano Institución Universitaria. 
We propose the following methodology for this analysis:

\section{Defining the area of study and time period}

Initially, a developing need was identified in the publication area due to the difficulty of finding media related to publishing consumer culture studies. Thus, we found a thematic opportunity relevant to students.

\section{Consumer culture studies}

In relation to consumers, one of the findings from the previous exercise identified the opportunity to take a closer look at consumer culture studies, finding an interesting number of texts and an emerging interest in this specific topic.

This is how a new exercise is constructed, which gives rise to a new SLR aimed at better understanding this phenomenon in greater depth, proposing a trend within the findings.

Through this procedure, this book identified the interest and relevance in developing this particular publishing project. It sought to again analyze and interpret a new search query that included new interests found in the previous study, and developed a different period of analysis, which yielded an initial equation of 634 texts that were subsequently refined to the database that is covered within this chapter. The result yielded a database of 385 articles devoted to research on consumer culture studies between 2011 and 2018, using the following search query in the Scopus database:

(TITLE-ABS-KEY ("consumer behavior" OR "consumer behavior") AND TITLEABS-KEY (cultur*) AND TITLE-ABS-KEY (marketing)) AND (LIMIT-TO (PUBYEAR, 2018) OR LIMIT-TO (PUBYEAR, 2017) OR LIMIT-TO (PUBYEAR, 2016) OR LIMIT-TO (PUBYEAR, 2015) OR LIMIT-TO (PUBYEAR, 2014) OR LIMIT-TO (PUBYEAR, 2013) OR LIMIT-TO (PUBYEAR, 2012) OR LIMIT-TO (PUBYEAR, 2011)).

For this review, certain variables and aspects of each of the texts analyzed were considered: purpose, marketing variable, hypotheses, instrument and information collection techniques, types of sampling, research, and information processing, results, and the country or population involved. 


\section{Publication trend}

Figure 1. Publication in Scopus, in accordance with the review.

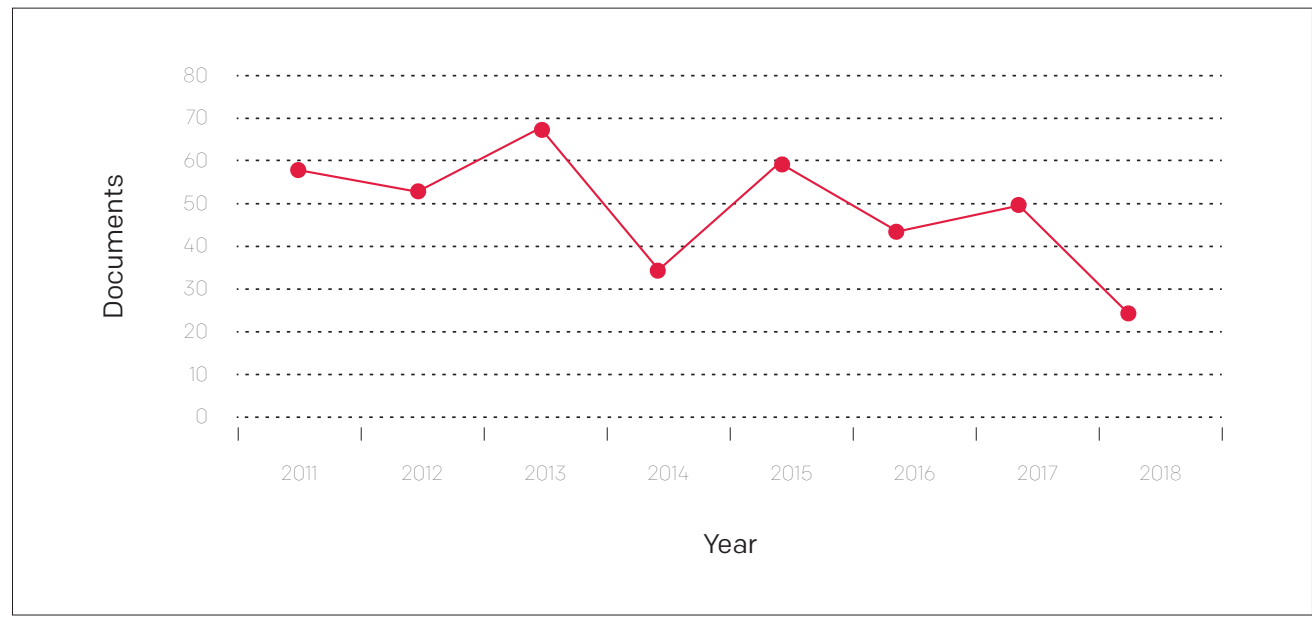

Source: Scopus.

It should first be noted that the research on consumer culture studies has remained an active and interesting topic, as it is seen as a publication trend, and is stable during the years of the review, with increased interest in 2013, remaining constant until 2017. We identified that, as of the date of the review, in publications for the current year, two publication periods are still missing, which explains the decreasing trend in 2018 as shown in Figure 1.

Below, the main publishers interested in the subject are shown.

\section{Source}

Asia Pacific Journal of Marketing and Logistics

British Food Journal 11

\begin{tabular}{l|l} 
International Marketing Review & 10
\end{tabular}

\begin{tabular}{l|l} 
Journal of Islamic Marketing & 10 \\
\hline
\end{tabular}

\begin{tabular}{l|l} 
European Journal of Marketing & 8
\end{tabular}

Journal of Business Research $\quad 8$

\begin{tabular}{l|l} 
Journal of Global Fashion Marketing & 8
\end{tabular}

\begin{tabular}{l|l} 
Journal of Consumer Marketing & 7
\end{tabular}

Table 1. Source: Scopus 
From this information, we can identify the means most interested in the subject analyzed, the different citation opportunities of greater relevance to select means of disseminating this trend, and the review of topics relevant to consumer culture studies for future studies.

\begin{tabular}{|l|c|}
\hline Language & Texts \\
\hline English & 378 \\
\hline Chinese & 2 \\
\hline Russian & 2 \\
\hline French & 1 \\
\hline German & 1 \\
\hline Spanish & 1 \\
\hline
\end{tabular}

Table 2. Source: Scopus

I $\mathrm{n}$ addition, we found that the predominant language in the journals consulted was English and that the country with the most case studies was the United States with 109 texts, followed by the United Kingdom with 49. This was one of the main reasons for deciding to publish the book in English, to have the widest visibility possible.

\section{Type of text according to publication format}

\begin{tabular}{|l|c|}
\hline Type of publication & Texts \\
\hline Article & 262 \\
\hline Book Chapter & 30 \\
\hline Conference Paper & 29 \\
\hline Book & 25 \\
\hline Conference Review & 15 \\
\hline Review & 12 \\
\hline Editorial & 6 \\
\hline News Article & 4 \\
\hline Letter & 1 \\
\hline
\end{tabular}

Table 3 Source: Scopus

Unlike the first study conducted, for this new analysis, all forms of publication were included in the search, to obtain a broader view. 
Regarding how they are circulated, we identified that $68.1 \%$ of the texts are published in scientific articles, which matches the publication trend in the marketing field overall, where $76.11 \%$ are published in this manner, which indicates a behavior similar to other forms of publication such as books where this percentage is only $6.5 \%$, compared to 7.18\% in books for marketing. This confirms the need to publish more in-depth data, justifying this book's publication.

\section{STUDY CONCEPT AND ASSOCIATED VARIABLES}

From the results analysis generated by the SLR, some main concepts were identified, which allow us to visualize the literature's progress.

\begin{tabular}{|l|c|}
\hline Study concept and associated variables & Text \\
\hline Big data analysis & 2 \\
\hline Co-creation & 2 \\
\hline Consumer behavior & 207 \\
\hline Consumer behavior; Consumer buying behavior; Cross-cultural & 1 \\
\hline Consumer behavior; Cross-cultural & 3 \\
\hline Consumer behavior; Cross-cultural; Mobile/online shopping & 1 \\
\hline Consumer behavior; Emerging markets; Cross-cultural & 1 \\
\hline Consumer behavior; Emerging markets; Mobile/online shopping & 1 \\
\hline Consumer behavior; Ethical consumption \& sustainability; Literature review & 1 \\
\hline Consumer behavior; Literature review & 2 \\
\hline Consumer behavior; Market segments & 3 \\
\hline $\begin{array}{l}\text { Consumer behavior; Market segments; Ethical consumption } \\
\text { \& sustainability; Cross-cultural }\end{array}$ & 2 \\
\hline Consumer behavior; Market segments; Mobile/online shopping & 1 \\
\hline Consumer behavior; Mobile/online shopping & 2 \\
\hline Consumer behavior; Mobile/online shopping; Cross-cultural & 5 \\
\hline Consumer behavior; Sustainable consumption & 1 \\
\hline Consumer buying behavior & 2 \\
\hline Consumer culture theory & 2 \\
\hline
\end{tabular}




\section{Study concept and associated variables}

Consumer culture theory; Consumer buying behavior

Consumer culture theory; Market segments

Cross-cultural

Cross-cultural; Market segments

Cross-cultural; Mobile/online shopping

Emerging markets

Ethical consumption \& sustainability

Ethical consumption \& sustainability; Cross-cultural

\begin{tabular}{|l|c|}
\hline Literature review & 1 \\
\hline Market segments & 10 \\
\hline Mobile/online shopping & 19 \\
\hline Mobile/online shopping; Cross-cultural & 1 \\
\hline Mobile/online shopping; Emerging markets & 1 \\
\hline Mobile/online shopping; Market segments & 1 \\
\hline Packaging & 1 \\
\hline Packaging, Sustainable consumption & 1 \\
\hline Practices of social innovation & 7 \\
\hline Practices of social innovation; Co-creation; Mobile/online shopping & 7 \\
\hline Practices of social innovation; Co-creation; & 7 \\
\hline Mobile/online shopping; Literature review & \\
\hline Practices of social innovation; Consumer buying behavior & 1 \\
\hline Practices of social innovation; Cross-cultural & 1 \\
\hline Practices of social innovation; Market segments & 35 \\
\hline Practices of social innovation; Mobile/online shopping & 1 \\
\hline Practices of social innovation; Mobile/online shopping & 2 \\
\hline Total, general & 1 \\
\hline
\end{tabular}

Table 3. Source: Created by the authors. 
With the consumer culture studies SLR, the great importance of analyzing consumer behavior is identified, where an interest in understanding this phenomenon occupies great part of the literature. From Table 3, we find 231 articles having this concept as their main motivation. It is worth mentioning two previous review articles regarding this particular topic from the works consulted. The first article (Kaufmann, Loureiro, Basile, \& Vrontis, 2012) explains the various stages of the evolution of the relationship between consumers and brands. The second conceptualization proposes a new pattern of segmentation and categorization of brand consumers and their respective behaviors derived from the different stages of development of the consumer-brand relationship integrating cultural aspects that lead to new segmentation patterns and socially responsible marketing. The second article (Al-Hyari, Alnsour, Al-Weshah, \& Haffar, 2012), related to understanding the concept from a religious perspective, gives researchers an opportunity to recognize the concept from a marketing/management perspective.

Within the SLR, there are 13 articles directly related to the topic of consumer culture Theory. These reviews raise five essential theoretical issues in basic and applied fields of study. The first suggests a detailed analysis of the processes and consequences of activities during use (Penz \& Stöttinger, 2015). The second explains activity meaning and actor motivations (Mitchell \& Imrie, 2011). The third predicts (shapes) what actions and results will occur and the impacts of attempts to influence before, during, and after getting involved (Granot, Alejandro, \& Russell, 2014). Finally, controlling or influencing beliefs, attitudes, behaviors, and assessments (Woodside, 2017). One of the most interesting articles is that of Ladik, Carrillat, and Tadajewski (2015), who argue that Belk's study within the theory of consumer culture is significant for the whole discipline, regardless of the paradigmatic position. The research presented aims to demonstrate that the article by Belk (1988) is possibly among the most influential articles ever published in JCR on the subject.

We can see a trend within the literature on consumer behavior toward studies associated with mobile/online shopping. The findings reflect similarities between markets, but also differences, related to consumers' motivation in using augmented reality systems to support their decision to buy online. It also suggests the need for retailers to consider online shopping to improve their success using the Internet (Swamp, Rese, \& Baier, 2017; Zendehdel, Paim, \& Delafrooz, 2016). For Hagag, Clark, and Wheeler (2015), there are several cultural frameworks, but they are not based on consumer behavior, whether online or offline. They consider this to be an opportunity in this area of research.

The term practices of social innovation is included in 27 texts, of which articles such as The effect on medical tourism of spreading cultural content online (Hong, Kwak, \& Kwak, 2016), which considers understanding the effect of consumer search behavior 
in the worldwide circulation of medical tourism. Another study suggests that consumers are moving from electronic channels to mobile channels and consider the effect of these technological innovations in retail environments from a cognitive perspective, where studies are limited (Swamp \& Priporas, 2016), which becomes a research opportunity. Additionally, Abou-Elgheit (2013) analyzes the enormous digital business environment in China for e-commerce, digital marketing, consumer behavior, IT outsourcing, software development, and innovation. The analysis reveals vast opportunities in China's digital social business that takes advantage of the collaborative culture for businesses and individual consumers. Finally, the study A cross-country study of consumer innovativeness and technological service innovation argues that the results of a multi-group structural equation modeling show that the relationship between consumer innovation capacity and attitude toward innovation varies in three dimensions: perceived novelty, perceived value, and perceived risk.

When reviewing the term Big Data analysis, the obtained bibliographic results yielded a limited number of texts, which could signify a research opportunity. In the research study big data and consumer behavior: imminent opportunities, Hofacker, Malthouse, and Sultan (2016) suggest that big data has the potential to broaden our understanding of each stage of the consumer decision-making process. While the field has traditionally progressed using first a theory followed by experimentation, it now appears that the nature of the feedback cycle between theory and results may change with the use of this technique. In another article Design and implementation of hadoop-based customer marketing big data processing system, Liu (Liu, 2016) argues that reliability and validity can be analyzed to determine the data collected, checking its correlation analysis, and the hypothesis model of regression analysis to obtain accurate marketing.

Co-creation is also a strong trend within publication, with more than 16 articles including this term within the SLR, and at least 14 of them are associated with the topic of consumer behavior. From the review, it is worth highlighting a study on the agricultural consumption of products that states in its findings that the quality of the product is the client's key motivator. Price is not a significant barrier in purchasing as long as the customer feels included (Murphy, 2011). Most of the texts related to this topic are included in proceedings and cover topics alluding to the effects of the policy of disseminating information about products, interactivity of social networks, and online consumer behavior, strategies to establish service-focused designs based on consumers and their degrees of involvement, the influence on general attitudes of sustainability and the congruence of values in consumer behavior among others ("International Conference on Information Systems, ICIS 2012, Volume 1," 2012; 2011; Volume 2," 2012; 2012, Volume 3," 2012, Volume 4," 2012; 2012, Volume 5," 2011; 2012, Volume 5," 2012). 
The growth of the term cross-cultural is present in 37 reviewed texts, involving concepts such as ethical consumption and sustainability (Yen, Wang, \& Yang, 2017). Another text consulted contributes decisively to group decision-making and joint decisions in segments that have not been widely researched: intercultural problems in emerging markets, emotions, and consumer misconduct (Cohen, Prayag, \& Moital, 2014). Another relevant text suggests a positive relationship between intrinsic religiosity and the belief that questionable consumer activities are not ethical. However, extrinsic religiosity does not affect consumer opinions about the ethics of consumer practices (Patwardhan, Keith, \& Vitell, 2012). The literature review showed a trend toward purchasing ethical foods (organic foods, fair trade products, and locally grown products), suggesting that this phenomenon can do more harm than good in the long term, in terms of the environment, nutrition, and health (Popa, Draghici, Popa, \& Niculita, 2011).

In relation to studying the relationship between culture and gender roles in the purchase and consumption of products, a book called Gender, culture, and consumer behavior is highlighted (Otnes \& Zayer, 2012). It offers innovative research on gender and consumer behavior with topics relevant to psychology, marketing, advertising, sociology, women's studies, and cultural studies. Another relevant study on gender shows how women go from being a wife in a consanguineous family in Nigeria, which they describe as patriarchal, to transforming their role in a nuclear family in the United Kingdom, a society to which they attribute gender equality (Lindridge, Peñaloza, $\&$ Worlu, 2016). In the research study Gender: As a purchasing decision variable and a research at Karamanoglu Mehmetbey University (Alagöz \& Burucuoglu, 2011), they attempt to explain the term gender in several categories and study its effects (like a subclass of personal factors) in buying behavior.

Finally, the cultural concept is provided by articles from the SLR that indicate the term consumer buying behavior, which highlights a study on the characteristics of country of origin ( $\mathrm{COO}$ ) products and seeks to understand the effects of these types of products between subnational cultural consumers, which is relevant given the increasing ethnic diversity of consumer markets (Shoham, Segev, \& Gavish, 2017). It is also worth noting a modeling of consumer buying behavior using the Z-Number concept (Shoham et al., 2017). In the study by Shoham et al. (2017), the concept of Z number is applied to handle uncertainties when analyzing consumer buying behavior. This concept is also related to another empirical study conducted with Korean American families in relation to values, attitudes, and behaviors related to fashion. In this study, two roles of fashion were identified in relation to the process of family assimilation. It refers to a strong relationship between the values of parents and children in the Korean American families interviewed (Lee \& Lee, 2015). 


\section{Methodology introduced by the texts reviewed.}

\begin{tabular}{|l|c|}
\hline Methodology & Number of texts \\
\hline Causal & 5 \\
\hline Descriptive & 3 \\
\hline Exploratory & 17 \\
\hline Mixed & 2 \\
\hline Qualitative & 318 \\
\hline Quantitative & 8 \\
\hline Total, general & $\mathbf{3 5 3}$ \\
\hline
\end{tabular}

Table 4 Source: created by the authors

The analysis of the methodologies used by these studies outlines a propensity for qualitative research in the knowledge area. Studies have a tendency toward empiricism.

Most of the documented research studies are studies aimed at describing a phenomenon. Only eight documents use quantitative methodologies and only two use mixed methodologies, which identifies an opportunity to conduct multidisciplinary research with experts in other knowledge areas.

\section{Instrument (scale, log, guide)}

\begin{tabular}{|l|c|}
\hline Instrument & Number of texts \\
\hline Guide & 18 \\
\hline Literature review & 7 \\
\hline Log & 158 \\
\hline Survey & 130 \\
\hline Scale & 40 \\
\hline Total, general & $\mathbf{3 5 3}$ \\
\hline
\end{tabular}

Table 5 Source: created by the authors

The instrument configuration is distributed between scales, logs, and guides, being logs as one of the most used instruments, followed by surveys, which accounts for the previously related methodologies. 


\section{Type of sampling}

\begin{tabular}{|l|c|}
\hline Sample type & Number of texts \\
\hline $\begin{array}{l}\text { Convenience } \\
\text { sampling }\end{array}$ & 4 \\
\hline Critical reading & 34 \\
\hline Observation & 249 \\
\hline Sampling & 10 \\
\hline $\begin{array}{l}\text { Simple Random } \\
\text { sample }\end{array}$ & 56 \\
\hline Total, general & $\mathbf{3 5 3}$ \\
\hline
\end{tabular}

Table 6 Source: created by the authors

In the previous table, the different types of information collection are connected. The various mechanisms used by the researcher to collect and record the information were taken from the SLR.

The technique is focused on the methodology. For some of the texts, there may be different information collection techniques, but for this analysis, the most relevant one was selected according to the method. 


\section{CONCLUSIONS}

This book's contributions can be very useful in identifying research opportunities, as well as being a useful tool for constructing basic concepts for future research.

The chapters proposed for this publication suggest an approach to some of these theoretical models identified within the SLR. Next, we will describe the common points found within the theoretical models that introduce the different chapters to guide readers on the relevance of their reading and opportunities to make progress in the state of the art of the topics.

Chapter 2:

EXPLORATION OF THE CONSUMER DECISION PROCESS: LUXURY FASHION PRODUCTS IN BOGOTÁ.

\section{Authors:}

Oscar Robayo-Pinzon PhD. (c)

Politécnico Grancolombiano Institución Universitaria

Bachelor's degree in psychology and Master's degree in consumer psychology from Konrad Lorenz University, and researches in the areas of consumer behavior, decisionmaking models, and brand choice patterns.

\section{Sandra Rojas-Berrío PhD.}

Assistant Professor, School of Economic Sciences, National University of Colombia.

\section{Diana Giraldo-López MS.}

Politécnico Grancolombiano Institución Universitaria

Professional in Business Administration with emphasis in Finances and Master in Strategic Marketing Management at the Institución Universitaria Politécnico Grancolombiano; with 10 years of experience in commercial area, marketing, customer loyalty, and sales channels.

This chapter is the product of a research that presents the results as a suggestion for marketing managers in this sector. It identifies the need to improve their marketing strategies, focusing on what their target audience is looking for. This research is the first to analyze the decision process in buying luxury fashion products in the city of Bogotá through the use of in-depth interviews. It shows potential given the thematic con- 
cordance found in nine texts within the database. One of the studies considered in the review is Digitalization, luxury fashion and "Chineseness": The influence of the Chinese context for luxury brands and the online luxury consumers experience (Rovai, 2018). This study proposes an understanding of the emerging problems arising from the Chinese consumer market, which influence the strategy of digitalization of luxury brands in China. This allows us to make a direct comparison to this chapter, with user experiences from two different social contexts. This study suggests the need to expand the result of the very limited research on the subject. This finding from the SLR indicates the potential for readers to compare the appreciation of luxury in two places as diverse as Bogotá and China using the cross-cultural concept.

Within the referenced studies, there is also concurrence with texts on fashion marketing strategies, a phenomenon that was also studied in Mexico (Rajagopal \& Rajagopal, 2017; Rajagopal, 2011). In Italy, generally, this is covered by S. Kim, Shimizu, and Donvito (2016); specifically in the city of Florence, by the authors Aiello, Donvito, Grazzini, and Petrucci (2016); in Korea, by Read and Lee (2015); in China, by Read and Lee (2015), which may be a complement to another study, Fashion phenomenon in postmodern marketing applications and effects on the marketing components proposed by (Aksu, Pektaş, \& Eseoğlu, 2011), which is complementary by researching the effects of the phenomenon of fashion on understanding marketing and applications in marketing components. As an alternative, the Istanbul Shopping Fest project is suggested, which aims to turn Istanbul into a shopping center as a global brand, primarily for European countries and Central Asia, and for other neighboring countries; not only using clothing and fashion products but also the distinctive values of clothing and food as cultural and tourist values. Finally, the article: The impact of country of origin and ethnocentrism as major dimensions in consumer purchasing behavior in fashion industry examines the impact of the $\mathrm{COO}$ and ethnocentrism on consumer purchasing behavior in the fashion industry, specifically in the fabric industry written by Abedniya and Zaeim (2011).

For Chapter 3:

INTERNET MARKETING COMMUNICATIONS OF TRADE ENTERPRISES IN UKRAINE.

\section{Author:}

\section{Tetiana Dubovyk Grand PhD (Economics)}

Professor, Department of Marketing and Advertising

Kyiv National University of Trade and Economics

Kyiv, Ukraine 
This chapter covers the study of the transformation of the Ukrainian economy as whole, activities by specific groups of commercial companies, and trends in the development of Internet marketing communications (InMC), from the concepts of consumer behavior, market segments, and mobile/online shopping's perspective. It is precisely relevant to the proposed publication because it considers the overlap of these concepts with at least 50 texts in the SLR. This chapter discusses overlap with six texts that deal with the concept of marketing communications. The analysis of Trade Enterprises is explained in the article How consumer mindsets in ethnic Chinese societies affect the intention to buy Fair Trade products: The mediating and moderating roles of moral identity (Yen et al., 2017) and in the article Strategies for trade sales in a changing Asian business culture (Leach, Liu, \& Pelton, 2011). Another important text for the Market Communication concept is Cross-Cultural Consumer Behavior: Use of Local Language for Market Communication-A Study in Region Friuli Venetia Giulia (Italy) (Rosa, Sillani, \& Vasciaveo, 2017). Another article that stands out from the SLR is Psychological, economic and social efficiency of advertising in modern marketing communications by Lebedev (2015). Its results from experimental studies on emotional assessments of commercial and social advertisements in altered states of consciousness and by people with mental pathologies are presented. Finally, it analyzes the correlations between consumers' personal characteristics and their assessments of commercial offers under different marketing communications. The communication phenomenon is also analyzed from the concept of consumer behavior in texts by Dogerlioglu-Demir and Tansuhaj (2011a, 2011b). The mediating and moderating roles of moral identity in the communication of products (Yen et al., 2017).

\section{Chapter 4:}

SIX MARKETING TYPOLOGIES IN SEARCH OF A CUSTOMER (WITH APOLOGIES TO LUIGI PIRANDELLO)

Author:

\section{Arthur Asa Berger, PhD \\ Professor Emeritus \\ Broadcast and Electronic Communication Arts \\ San Francisco State University}

In analyzing two of the most popular marketing typologies, the VALS 1 and 2 typology and the Claritas typology, the possible use of a third typology that could complement the benefits of the first two is suggested. The author argues that these typologies have certain shortcomings and suggests a third typology called grid-group that considers the existence of four lifestyles (consumer cultures) that oppose each other but shape 
consumer preferences for community members. The concept discussed in this chapter synthesizes another publication by the author, Ads, Fads, and Consumer Culture (Berger, 2011), other texts identified that refer to the VALS typology are: (Chang, 2011, 2013; Fornerino, Jolibert, Sánchez, \& Zhang, 2011; Karami, Olfati, \& Dubinsky, 2017; J. Kim \& Kim, 2014; Ogden \& Cheng, 2011; Raij \& Riekki, 2012). Regarding grid-group analysis, by (Li, Zhang, Xiao, \& Chen, 2015). Another relevant text within the SLR is: A typology of internet users based on comparative affective states: Evidence from eight countries (Christodoulides, Michaelidou, \& Siamagka, 2013), whose study proposes the distinction of affective typologies based on the intentions of Internet users, which uses comparable samples from four Western and four East Asian countries. The chapter fits into the publication through the concepts of cross-cultural and consumer behavior, some texts relevant in the review are presented in this chapter, such as the one considered in Cultural persuasive affordances in advergaming design across cultures: A conceptual model (Wanick, Ranchhod, \& Wills, 2015) introduces a conceptual framework with the integration of cultural persuasion opportunities that could be considered in studies that involve persuasion, play, branding, and intercultural consumer behavior. Also, the results of another study whose findings suggest that attitudes toward materialism directly affect consumer behavior, and therefore marketing strategy (Moore \& Berger, 2015). In addition, some studies address the concept of lifestyles (Popa et al., 2011; Grybovych, Lankford, \& Lankford, 2013), and more recently (Muralidharan \& Xue, 2016).

\section{Chapter 5:}

THE RELATION BETWEENCULTUREAND PSYCHOLOGICAL PROCESSESOF CONSUMERS: ATTRIBUTES-CONSEQUENCES-VALUES LINKAGES VARIATIONS.

Author:

\section{Byung-Joon CHOI PHD. in Marketing CNU.}

Assistant Professor of Marketing

European Business School Paris

This chapter argues that primary consumers with holistic thinking consider broader connections between the key perceptive elements of the series of means and ends, providing support for the dynamics of culture-specific thinking styles, such as the driver of cultural variations, in consumers' cognitive complexity during the decision-making process. Important marketing perspectives arise from the results of this empirical multicultural study. The decision-making process concept is developed by (Pantano et al., 2017; Razzaque \& Chaudhry, 2013). This chapter, framed within the concepts 
of consumer behavior, emerging markets, and cross-cultural, is associated with 36 texts from the review conducted, and is similar to the concept in the article Hispanic marketing: A cultural perspective (Korzenny \& Korzenny, 2012), and it can be interpreted from the studies of consumers' responses to CSR in a cross-cultural setting (Karaosman, Morales-Alonso, \& Grijalvo, 2015). Cross-cultural research in international marketing: clearing up some of the confusion (from Mooij, 2015). Students' attitudes to marketing communications: Cross-cultural aspects (Romanova \& Noskova, 2015), which defines the influence of different elements of the culture model (cultural values, elements of material, and institutional environment) in the attitudes of Russian and Chinese students toward marketing communications.

We end external contributions with Chapter 6:

MARKETING RESEARCH PROCESSES. A PERSPECTIVE OF THE FUTURE FROM A QUALITATIVE VIEW.

Authors:

\section{Luz Alexandra Montoya-Restrepo PhD.}

Associate Professor, School of Mining, National University of Colombia.

\section{Iván Alonso Montoya Restrepo PhD.}

Associate Professor, School of Agricultural Sciences, National University of Colombia

\section{Sandra Rojas-Berrío PhD.}

Assistant Professor, School of Economic Sciences, National University of Colombia.

The research will focus on the future as a discipline highly associated with sensory and neurological studies, produced with social networking strategies, and aimed at describing specific phenomena with an ethnographic focus, which will develop a new scientific anthropology-marketing, associated with the concepts of social innovation practices, co-creation, and consumer behavior. It is directly related to 17 texts from the literature review, particularly highlighting its similarity with the article Reinventing the Role of Consumer Research in Today's Open Innovation Ecosystem (Moskowitz \& Saguy, 2013), which suggests contributions to science through consumer Research (CR). The text indicates the need to apply open innovation principles and promote innovation focused on the consumer, proposing the use of social networking strategies. It also suggests the potential identification of seven paradigm changes regarding consumers' roles and how to interact with them. Other elements suggested by the authors of this chapter, such as 
new consumer needs or unsatisfied needs or those that can be better managed, are also explored by authors from the SLR, including (Roozmand et al., 2011; Koo \& Le, 2014; Cova, Kozinets, \& Shankar, 2012). Also, the issue of purchasing decision-making mechanisms are explored by (Berčík, Horská, Gálová, \& Margianti, 2016; Hofacker et al., 2016). Articles regarding product use or utilization are also identified. We find developments related to market research in articles by (Akturan, Tezcan, \& Vignolles, 2011; Allen, Byon, \& Drane, 2011; Atkinson, Nelson, \& Rademacher, 2015; Chekima, Khalid Wafa, Igau, \& Chekima, 2015; Cohen et al., 2014; Feinberg, 2012; Ferguson \& Phau, 2012; Hernando \& Campo, 2017; Morhart, Malär, Guèvremont, Girardin, \& Grohmann, 2013; Opoku, 2012; Pennington, 2015; Pocol \& Bolboacă, 2013; Rehman, 2017; Robson, Pitt, \& Wallstrom, 2013; Sadikoglu, 2017; Shavitt, Jiang, \& Cho, 2016; Shin, 2012; Shoham et al., 2017; Tifferet \& Herstein, 2012; Wróblewski, Dacko-Pikiewicz, \& Cuyler, 2017).

\section{REFERENCES}

Abedniya, A., \& Zaeim, M. N. (2011). The impact of country of origin and ethnocentrism as major dimensions in consumer purchasing behavior in fashion industry. European Journal of Economics, Finance and Administrative Sciences, (33), 222-232. Retrieved from https://www. scopus.com/inward/record.uri?eid=2-s2.0-79959705358 \&partnerID=40\&md5=65d410c2f6dca85fc7aed3229438e6e0

Abou-Elgheit, E. (2013). The digital Guanxi: China's digital business in light of recent transformation. 2013 International Conference on Information Society, i-Society 2013, 200-206. Retrieved from https://www.scopus.com/inward/record.uri?eid=2-s2.0-84890834571\&partnerID=40\&md5=eb238daa040d81963b5a378da21b9fbc

Aiello, G., Donvito, R., Grazzini, L., \& Petrucci, E. (2016). The relationship between the territory and fashion events: The case of Florence and Pitti Immagine fashion fairs. Journal of Global Fashion Marketing, 7(3), 150-165. https://doi.org/10.1080/20932685.2016.1166714

Aksu, M., Pektaş, G. O. E., \& Eseoğlu, M. (2011). Fashion phenomenon in postmodern marketing applications and effects on the marketing components. 7th International Strategic Management Conference, 24, 325-339. https://doi.org/10.1016/j.sbspro.2011.09.126

Akturan, U., Tezcan, N., \& Vignolles, A. (2011). Segmenting young adults through their consumption styles: A cross-cultural study. Young Consumers, 12(4), 348-360. https://doi. org/10.1108/17473611111185896

Al-Hyari, K., Alnsour, M., Al-Weshah, G., \& Haffar, M. (2012). Religious beliefs and consumer behaviour: From loyalty to boycotts. Journal of Islamic Marketing, 3(2), 155-174. https://doi. org/10.1108/17590831211232564

Alagöz, S. B., \& Burucuoglu, M. (2011). Gender: As a purchasing decision variable and a research at Karamanoglu Mehmetbey University. European Journal of Economics, Finance and Administrative Sciences, (39), 94-100. Retrieved from https://www.scopus.com/inward/record. uri?eid=2-s2.0-80054806694\&partnerID $=40 \& \mathrm{md5}=2 \mathrm{ecb} 971 \mathrm{c} 4 \mathrm{ff} 7 \mathrm{c588e} 12945 \mathrm{c} 1 \mathrm{cf} 86 \mathrm{~b} 0 \mathrm{~b} 3$ 
Allen, J. T., Byon, K. K., \& Drane, D. D. (2011). International students' sport spectator behavior: Socialization and cultural expression. In Social and Psychological Issues in Sports (pp. 191-216). Retrieved from https://www.scopus.com/inward/record.uri?eid=2-s2.0-84896567134\&part-

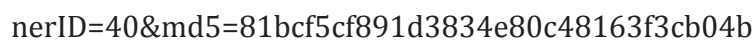

Atkinson, L., Nelson, M. R., \& Rademacher, M. A. (2015). A Humanistic approach to understanding child consumer socialization in US homes. Journal of Children and Media, 9(1), 95-112. https://doi.org/10.1080/17482798.2015.997106

Belk, R. (1988). Possessions and the Extended Self. Journal of Consumer Research, 15(2), 139-168. https://doi.org/10.1086/209154

Berčík, J., Horská, E., Gálová, J., \& Margianti, E. S. (2016). Consumer neuroscience in practice: The impact of store atmosphere on consumer behavior. Periodica Polytechnica Social and Management Sciences, 24(2), 96-101. https://doi.org/10.3311/PPso.8715

Berger, A. A. (2011). Ads, Fads, and Consumer Culture. Advertising's Impact on American Character and Society, p. 258. Retrieved from http://books.google.com/books?id=5B8yXtjEsbkC\&printsec=frontcover \&dq=intitle:Ads+Fads+and+Consumer+Culture \&hl=\&cd=1\&source=gbs api\%5Cnpapers3://publication/uuid/D6565543-930B-4D13-BB83-AD8D404C6BED

Brereton, P., Kitchenham, B. A., Budgen, D., Turner, M., \& Khalil, M. (2007). Lessons from applying the systematic literature review process within the software engineering domain. Journal of Systems and Software, 80(4), 571-583. https://doi.org/10.1016/j.jss.2006.07.009

Chang, E. C. (2011). Consumer market segmentation in China. In Handbook of Contemporary Marketing in China: Theories and Practices (pp. 185-208). Retrieved from https://www.scopus.com/ inward/record.uri?eid=2-s2.0-84896169791\&partnerID=40\&md5=f6ff991a5a6249797deae6dd5db631f5

Chang, E. C. (2013). Consumer market segmentation in China. In Handbook of Contemporary Marketing in China: Theories and Practices (pp. 185-208). Retrieved from https://www.scopus.com/inward/record.uri?eid=2-s2.0-84896234070\&partnerID=40\&md5=ea5826ccacca456128799f8c53b6b991

Chekima, B., Khalid Wafa, S. A. W. S., Igau, O. A., \& Chekima, S. (2015). Determinant factors of consumers' green purchase intention: The moderating role of environmental advertising. Asian Social Science, 11(10), 318-329. https://doi.org/10.5539/ass.v11n10p318

Christodoulides, G., Michaelidou, N., \& Siamagka, N. T. (2013). A typology of internet users based on comparative affective states: Evidence from eight countries. European Journal of Marketing, 47(1), 153-173. https://doi.org/10.1108/03090561311285493

Cohen, S. A., Prayag, G., \& Moital, M. (2014). Consumer behaviour in tourism: Concepts, influences and opportunities. Current Issues in Tourism, 17(10), 872-909. https://doi.org/10.1080/136 83500.2013.850064

Cova, B., Kozinets, R. V, \& Shankar, A. (2012). Consumer tribes. In Consumer Tribes. https://doi. org/10.4324/9780080549743

Crema, M., \& Verbano, C. (2013). Guidelines for overcoming hospital managerial challenges: A systematic literature review. Therapeutics and Clinical Risk Management, 9(1), 427-441. https:// doi.org/10.2147/TCRM.S54178 
de Mooij, M. (2015). Cross-cultural research in international marketing: clearing up some of the confusion. International Marketing Review, 32(6), 646-662. https://doi.org/10.1108/IMR12-2014-0376

Dogerlioglu-Demir, K., \& Tansuhaj, P. (2011a). Global vs local brand perceptions among Thais and Turks. Asia Pacific Journal of Marketing and Logistics, 23(5), 667-683. https://doi. org/10.1108/13555851111183084

Dogerlioglu-Demir, K., \& Tansuhaj, P. (2011b). Global vs local brand perceptions among Thais and Turks. Asia Pacific Journal of Marketing and Logistics, 23(5), 667-683. https://doi. org/10.1108/13555851111183084

Feinberg, F. M. (2012). Mediation analysis and categorical variables: Some further frontiers. Journal of Consumer Psychology, 22(4), 595-598. https://doi.org/10.1016/j.jcps.2012.03.007

Ferguson, G., \& Phau, I. (2012). A cross-national investigation of university students' complaining behaviour and attitudes to complaining. Journal of International Education in Business, 5(1), 50-70. https://doi.org/10.1108/18363261211261755

Fornerino, M., Jolibert, A., Sánchez, C. M., \& Zhang, M. (2011). Do values or goals better explain intent? A cross-national comparison. Journal of Business Research, 64(5), 490-496. https:// doi.org/10.1016/j.jbusres.2010.03.007

Granot, E., Alejandro, T. B., \& Russell, L. T. M. (2014). A socio-marketing analysis of the concept of cute and its consumer culture implications. Journal of Consumer Culture, 14(1), 66-87. https://doi.org/10.1177/1469540513485274

Grybovych, O., Lankford, J., \& Lankford, S. (2013). Motivations of wine travelers in rural Northeast Iowa. International Journal of Wine Business Research, 25(4), 285-309. https://doi. org/10.1108/IJWBR-07-2012-0023

Hagag, W., Clark, L., \& Wheeler, C. (2015). A framework for understanding the website preferences of Egyptian online travel consumers. International Journal of Culture, Tourism, and Hospitality Research, 9(1), 68-82. https://doi.org/10.1108/IJCTHR-03-2013-0008

Hernando, E., \& Campo, S. (2017). An artist's perceived value: Development of a measurement scale. International Journal of Arts Management, 19(3), 33-47. Retrieved from https:// www.scopus.com/inward/record.uri?eid=2-s2.0-85028940500\&partnerID=40\&md5=f486327941aadc4b97da4ad0db8171a1

Hofacker, C. F., Malthouse, E. C., \& Sultan, F. (2016). Big Data and consumer behavior: imminent opportunities. Journal of Consumer Marketing, 33(2), 89-97. https://doi.org/10.1108/JCM04-2015-1399

Hong, J.-W., Kwak, Y.-S., \& Kwak, Y.-S. (2016). The effect of diffusion of online culture content on medical tourism: Analysis of keyword. International Journal of Database Theory and Application, 9(11), 293-304. https://doi.org/10.14257/ijdta.2016.9.11.26

International Conference on Information Systems, ICIS 2012, Volume 1. (2012). International Conference on Information Systems, ICIS 2012, 1. Retrieved from https://www. scopus.com/inward/record.uri?eid=2-s2.0-84886536369\& partner ID =40\& md5=9ad75527585a4798835d4fbb73864ebf 
International Conference on Information Systems, ICIS 2012, Volume 2. (2011). 32nd International Conference on Information System 2011, ICIS 2011, 2. Retrieved from https://www. scopus.com/inward/record.uri?eid=2-s2.0-84884643093\&partnerID=40\&md5=27 fade6ac3f03a37cb6cf606f1c7b775

International Conference on Information Systems, ICIS 2012, Volume 2. (2012). International Conference on Information Systems, ICIS 2012, 2. Retrieved from https://www.scopus.com/inward/record.uri?eid=2-s2.0-84886483941\&partnerID=40\&md5=6cd9bfdd6a2af8d9c158ec51172c5a42

International Conference on Information Systems, ICIS 2012, Volume 3. (2012). International Conference on Information Systems, ICIS 2012, 3. Retrieved from https://www.scopus.com/ inward/record.uri?eid=2-s2.0-84886470101\&partnerID=40\&md5=7f51e14982a32277bb87f17300c42c60

International Conference on Information Systems, ICIS 2012, Volume 4. (2012). International Conference on Information Systems, ICIS 2012, 4. Retrieved from https://www.scopus. com/inward/record.uri?eid=2-s2.0-84886483021\&partnerID=40\&md5=70b50ba9af00fc697b1ff4ef4921fad6

International Conference on Information Systems, ICIS 2012, Volume 5. (2011). 32nd International Conference on Information System 2011, ICIS 2011, 5. Retrieved from https://www. scopus.com/inward/record.uri?eid=2-s2.0-84884667362\&partnerID=40\&md5=e103cbe40f0093afbd6072db2985328e

International Conference on Information Systems, ICIS 2012, Volume 5. (2012). International Conference on Information Systems, ICIS 2012, 5. Retrieved from https://www.scopus.com/ inward/record.uri?eid=2-s2.0-84886550717\&partnerID=40\&md5=2441a03d215ae7a1b04bc5151531cada

Karami, M., Olfati, O., \& Dubinsky, A. J. (2017). Key cultural values underlying consumers' buying behaviour: a study in an Iranian context. Journal of Islamic Marketing, 8(2), 289-308. https:// doi.org/10.1108/JIMA-06-2015-0039

Karaosman, H., Morales-Alonso, G., \& Grijalvo, M. (2015). Consumers' responses to CSR in a cross-cultural setting. Cogent Business and Management, 2(1). https://doi.org/10.1080/233 11975.2015.1052916

Kaufmann, H. R., Loureiro, S. M. C., Basile, G., \& Vrontis, D. (2012). The increasing dynamics between consumers, social groups and brands. Qualitative Market Research, 15(4), 404-419. https://doi.org/10.1108/13522751211257088

Kim, J., \& Kim, J.-E. (2014). Making customer engagement fun: Customer-salesperson interaction in luxury fashion retailing. Journal of Fashion Marketing and Management, 18(2), 133-144. https://doi.org/10.1108/JFMM-04-2013-0050

Kim, S., Shimizu, A., \& Donvito, R. (2016). Italian fashion case study. Journal of Global Fashion Marketing, 7(3), 147-149. https://doi.org/10.1080/20932685.2016.1166711

Kitchenham, B. (2004). Procedures for performing systematic reviews. Keele, UK, Keele University, 33(TR/SE-0401), 28. https://doi.org/10.1.1.122.3308 
Koo, F. K., \& Le, H. (2014). Understanding culture, motivation, and ethnic consumer behavior. In Handbook of Research on Effective Marketing in Contemporary Globalism (pp. 47-65). https://doi.org/10.4018/978-1-4666-6220-9.ch003

Korzenny, F., \& Korzenny, B. A. (2012). Hispanic marketing: A cultural perspective. In Hispanic Marketing: A Cultural Perspective. https://doi.org/10.4324/9780080478357

Ladik, D., Carrillat, F., \& Tadajewski, M. (2015). Belk's (1988) "possessions and the extended self" revisited. Journal of Historical Research in Marketing, 7(2), 184-207. https://doi. org/10.1108/JHRM-06-2014-0018

Leach, M. P., Liu, A. H., \& Pelton, L. E. (2011). Strategies for trade sales in a changing asian business culture. Journal of Marketing Channels, 18(3), 217-239. https://doi.org/10.108 0/1046669X.2011.584299

Lebedev, A. N. (2015). Psychological, economic and social efficiency of advertising in modern marketing communications. Psikhologicheskii Zhurnal, 36(2), 5-19. Retrieved from https://www.scopus.com/inward/record.uri?eid=2-s2.0-84958690119\&partnerID=40\&md5=baabac2b72eccc885c09a87af73f1897

Lee, J., \& Lee, Y.-J. (2015). Acculturation for fashion consumer behavior: A case of Korean-American families. Journal of Global Fashion Marketing, 6(4), 278-291. https://doi.org/10.108 $0 / 20932685.2015 .1070683$

Li, M., Zhang, H., Xiao, H., \& Chen, Y. (2015). A grid-group analysis of tourism motivation. International Journal of Tourism Research, 17(1), 35-44. https://doi.org/10.1002/jtr.1963

Lim, H., Yoo, E.-H., \& Park, M. (2018). Warehouse rental market segmentation using spatial profile regression. Journal of Transport Geography, 73, 64-74. https://doi.org/10.1016/j. jtrangeo.2018.10.007

Lindridge, A., Peñaloza, L., \& Worlu, O. (2016). Agency and empowerment in consumption in relation to a patriarchal bargain: The case of Nigerian immigrant women in the UK. European Journal of Marketing, 50(9-10), 1652-1671. https://doi.org/10.1108/EJM-07-2011-0365

Liu, Y. (2016). Design and implementation of hadoop-based customer marketing big data processing system. International Journal of Database Theory and Application, 9(12), 331-340. https://doi.org/10.14257/ijdta.2016.9.12.29

López, A., Méndez, D., Paz, A., \& Arboleda, H. (2016). Desarrollo e Instrumentación de un Proceso de Vigilancia Tecnológica basado en Protocolos de Revisión Sistemática de la Literatura. Development and Implementation of a Technology Surveillance Process Based on Systematic Literature Review Protocols., 27(4), 155-164. https://doi.org/10.4067/S071807642016000400017

Maciejewski, G., Mokrysz, S., \& Wróblewski, Ł. (2019). Segmentation of coffee consumers using sustainable values: Cluster analysis on the Polish coffee market. Sustainability (Switzerland), 11(3). https://doi.org/10.3390/su11030613

Mitchell, C., \& Imrie, B. C. (2011). Consumer tribes: Membership, consumption and building loyalty. Asia Pacific Journal of Marketing and Logistics, 23(1), 39-56. https://doi. org/10.1108/13555851111099989 
Moore, K. A., \& Berger, P. D. (2015). Materialism and consumer behavior: Differences in types of materialism among different cultures. Indian Journal of Marketing, 45(1), 9-18. https://doi. org/10.17010/ijom/2015/v45/i1/79995

Morhart, F., Malär, L., Guèvremont, A., Girardin, F., \& Grohmann, B. (2013). Brand authenticity: An integrative framework and measurement scale. Journal of Consumer Psychology, 25(2), 200-218. https://doi.org/10.1016/j.jcps.2014.11.006

Moskowitz, H. R., \& Saguy, I. S. (2013). Reinventing the Role of Consumer Research in Today's Open Innovation Ecosystem. Critical Reviews in Food Science and Nutrition, 53(7), 682-693. https://doi.org/10.1080/10408398.2010.538093

Muralidharan, S., \& Xue, F. (2016). Personal networks as a precursor to a green future: a study of "green" consumer socialization among young millennials from India and China. Young Consumers, 17(3), 226-242. https://doi.org/10.1108/YC-03-2016-00586

Murphy, A. J. (2011). Farmers' markets as retail spaces. International Journal of Retail and Distribution Management, 39(8), 582-597. https://doi.org/10.1108/09590551111148668

Ogden, H., \& Cheng, S. (2011). Cultural dimensions and materialism: Comparing canada and china. Asia Pacific Journal of Marketing and Logistics, 23(4), 431-447. https://doi. org/10.1108/13555851111165011

Opoku, R. (2012). Young Saudi adults and peer group purchase influence: A preliminary investigation. Young Consumers, 13(2), 176-187. https://doi.org/10.1108/17473611211233549

Otnes, C. C., \& Zayer, L. T. (2012). Gender, culture, and consumer behavior. In Gender, Culture, and Consumer Behavior. https://doi.org/10.4324/9780203127575

Pantano, E., \& Priporas, C.-V. (2016). The effect of mobile retailing on consumers' purchasing experiences: A dynamic perspective. Computers in Human Behavior, 61, 548-555. https:// doi.org/10.1016/j.chb.2016.03.071

Pantano, E., Rese, A., \& Baier, D. (2017). Enhancing the online decision-making process by using augmented reality: A two country comparison of youth markets. Journal of Retailing and Consumer Services, 38, 81-95. https://doi.org/10.1016/j.jretconser.2017.05.011

Patwardhan, A. M., Keith, M. E., \& Vitell, S. J. (2012). Religiosity, Attitude Toward Business, and Ethical Beliefs: Hispanic Consumers in the United States. Journal of Business Ethics, 110(1), 61-70. https://doi.org/10.1007/s10551-011-1147-8

Pennington, R. (2015). Branding cultural analogues in virtual communities. In Strategic E-Commerce Systems and Tools for Competing in the Digital Marketplace (pp. 117-138). https:// doi.org/10.4018/978-1-4666-8133-0.ch006

Penz, E., \& Stöttinger, B. (2015). Consuming "European": Capturing homogeneity and heterogeneity in consumer culture of five European countries. European Journal of International Management, 9(3), 326-341. https://doi.org/10.1504/EJIM.2015.069162

Petersen, K., Feldt, R., Mujtaba, S., \& Mattsson, M. (2008). Systematic Mapping Studies in Software Engineering. 12Th International Conference on Evaluation and Assessment in Software Engineering, 17, 10. https://doi.org/10.1142/S0218194007003112 
Pocol, C. B., \& Bolboacă, S. D. (2013). Perceptions and trends related to the consumption of honey: A case study of North-West Romania. International Journal of Consumer Studies, 37(6), 642-649. https://doi.org/10.1111/ijcs.12046

Popa, A., Draghici, M., Popa, M., \& Niculita, P. (2011). Consumer choice and food policy. A literature review. Journal of Environmental Protection and Ecology, 12(2), 708-717. Retrieved from https://www.scopus.com/inward/record.uri?eid=2-s2.0-79960773213\&partnerID=40\&md5=a0be01a11af54f067609714dbe94077d

Raij, T. T., \& Riekki, T. J. J. (2012). Poor supplementary motor area activation differentiates auditory verbal hallucination from imagining the hallucination. NeuroImage: Clinical, 1(1), 75-80. https://doi.org/10.1016/j.nicl.2012.09.007

Rajagopal. (2011). Consumer culture and purchase intentions toward fashion apparel in Mexico. Journal of Database Marketing and Customer Strategy Management, 18(4), 286-307. https:// doi.org/10.1057/dbm.2011.33

Rajagopal, \& Rajagopal, A. (2017). Brand competition, peer influence, and purchase intentions towards fashion apparel in Mexico. International Journal of Business Excellence, 12(3), 386-412. https://doi.org/10.1504/IJBEX.2017.084455

Razzaque, M. A., \& Chaudhry, S. N. (2013). Religiosity and Muslim consumers' decision-making process in a non-Muslim society. Journal of Islamic Marketing, 4(2), 198-217. https://doi. org/10.1108/17590831311329313

Rehman, V. (2017). Looking through the Glass of Indian Culture: Consumer Behaviour in Modern and Postmodern Era. Global Business Review, 18(3_suppl), S19-S37. https://doi. org/10.1177/0972150917693139

Robson, K., Pitt, L., \& Wallstrom, A. (2013). Creative market segmentation: Understanding the bugs in consumer behavior. Journal of Public Affairs, 13(2), 218-223. https://doi.org/10.1002/ pa.1477

Romanova, I. M., \& Noskova, E. V. (2015). Students' attitude to the marketing communications: Cross-cultural aspects. Journal of Advanced Research in Law and Economics, 6(1), 177-185. https://doi.org/10.14505/jarle.v6.1(11).20

Roozmand, O., Ghasem-Aghaee, N., Hofstede, G. J., Nematbakhsh, M. A., Baraani, A., \& Verwaart, T. (2011). Agent-based modeling of consumer decision making process based on power distance and personality. Knowledge-Based Systems, 24(7), 1075-1095. https://doi.org/10.1016/j.knosys.2011.05.001

Rosa, F., Sillani, S., \& Vasciaveo, M. (2017). Cross-Cultural Consumer Behavior: Use of Local Language for Market Communication-A Study in Region Friuli Venetia Giulia (Italy). Journal of Food Products Marketing, 23(6), 621-648. https://doi.org/10.1080/10454446.2015.1048029

Rovai, S. (2018). Digitalisation, luxury fashion and "Chineseness": The influence of the Chinese context for luxury brands and the online luxury consumers experience. Journal of Global Fashion Marketing, 9(2), 116-128. https://doi.org/10.1080/20932685.2018.1435294

Sadikoglu, G. (2017). Modeling of Consumer Buying Behaviour Using Z-Number Concept. Intelligent Automation and Soft Computing, pp. 1-5. https://doi.org/10.1080/10798587.2017.1327159 
Shavitt, S., Jiang, D., \& Cho, H. (2016). Stratification and segmentation: Social class in consumer behavior. Journal of Consumer Psychology, 26(4), 583-593. https://doi.org/10.1016/j. jcps.2016.08.005

Shin, D.-H. (2012). Cross-analysis of usability and aesthetic in smart devices: What influences users' preferences? Cross Cultural Management, 19(4), 563-587. https://doi. org/10.1108/13527601211270020

Shoham, A., Segev, S., \& Gavish, Y. (2017). The effect of acculturation and ethnic identification on consumer disidentification and consumption: An investigation of U.S. Hispanics. Journal of Consumer Behaviour, 16(5), 403-412. https://doi.org/10.1002/cb.1640

Steenkamp, J.-B. E. M., \& Ter Hofstede, F. (2002). International market segmentation: Issues and perspective. International Journal of Research in Marketing, 19(3), 185-213. https://doi. org/10.1016/S0167-8116(02)00076-9

Tifferet, S., \& Herstein, R. (2012). Need for cognition as a predictor of store brand preferences. EuroMed Journal of Business, 7(1), 54-65. https://doi.org/10.1108/14502191211225374

Wanick, V., Ranchhod, A., \& Wills, G. (2015). Cultural persuasive affordances in advergaming design across cultures: A conceptual model. 19th International Academic Mindtrek Conference, AcademicMindTrek 2015, 63-68. https://doi.org/10.1145/2818187.2818293

Woodside, A. G. (2017). Solving the core theoretical issues in consumer behavior in tourism. Advances in Culture, Tourism and Hospitality Research, Vol. 13, pp. 141-168. https://doi. org/10.1108/S1871-317320170000013008

Wróblewski, Ł., Dacko-Pikiewicz, Z., \& Cuyler, A. C. (2017). The European union consumer behaviour in the festivals market in Poland . Polish Journal of Management Studies, 16(2), 302314. https://doi.org/10.17512/pjms.2017.16.2.26

Yen, G.-F., Wang, R.-Y., \& Yang, H.-T. (2017). How consumer mindsets in ethnic Chinese societies affect the intention to buy Fair Trade products: The mediating and moderating roles of moral identity. Asia Pacific Journal of Marketing and Logistics, 29(3), 553-568. https://doi. org/10.1108/APJML-06-2016-0107

Zendehdel, M., Paim, L. H., \& Delafrooz, N. (2016). The moderating effect of culture on the construct factor of perceived risk towards online shopping behaviour. Cogent Business and Management, 3(1). https://doi.org/10.1080/23311975.2016.1223390 


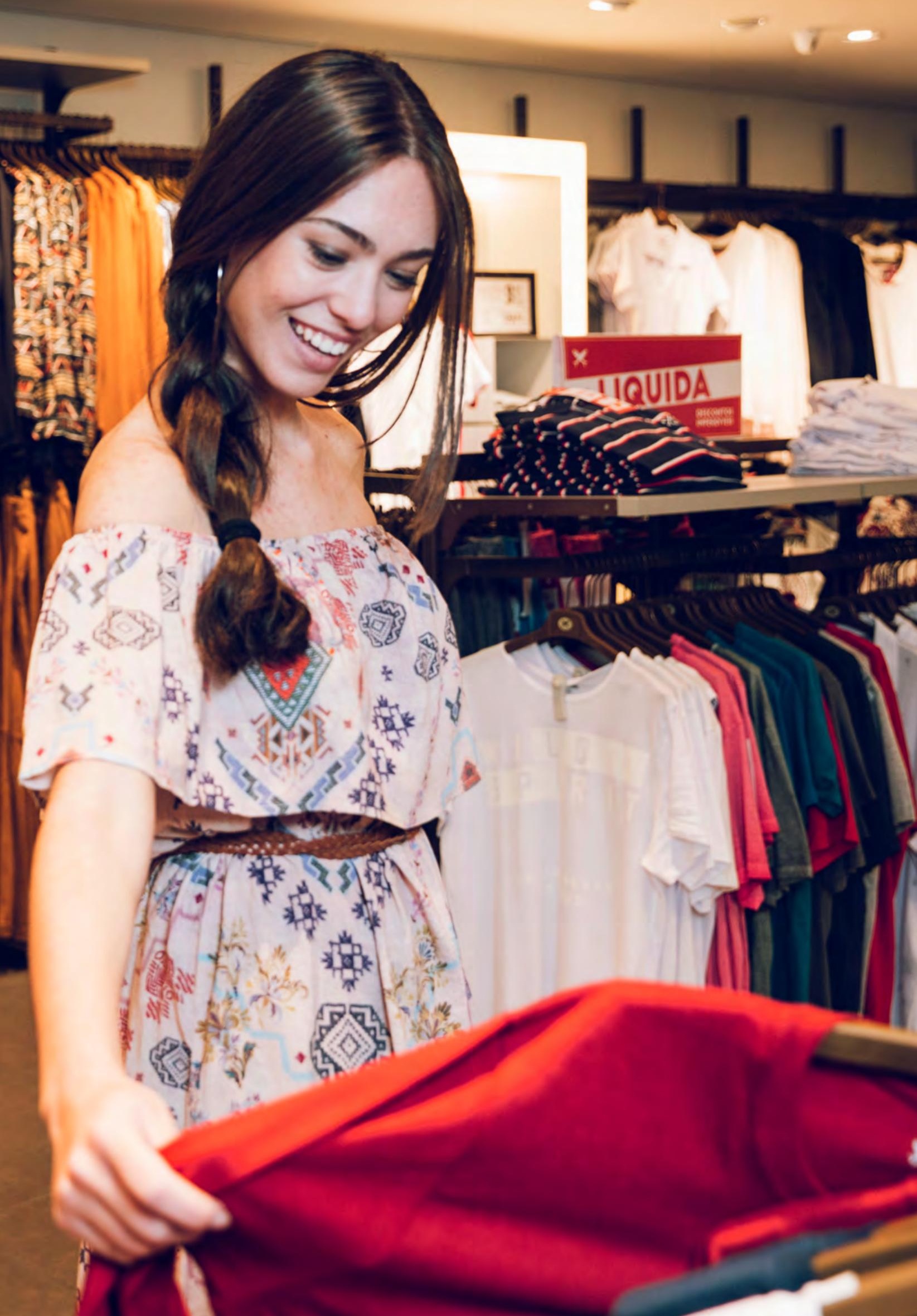

